\title{
Mechanistic Study on Iron Solubility in Atmospheric Mineral Dust Aerosol: Roles of Titanium, Dissolved Oxygen, and Solar Flux in Solutions Containing Different Acid Anions
}

Eshani Hettiarachchi and Gayan Rubasinghege*

Department of Chemistry, New Mexico Institute of Mining and Technology, Socorro, NM, 87801 eshani.hettiarachchi@student.nmt.edu

*gayan.rubasinghege@nmt.edu
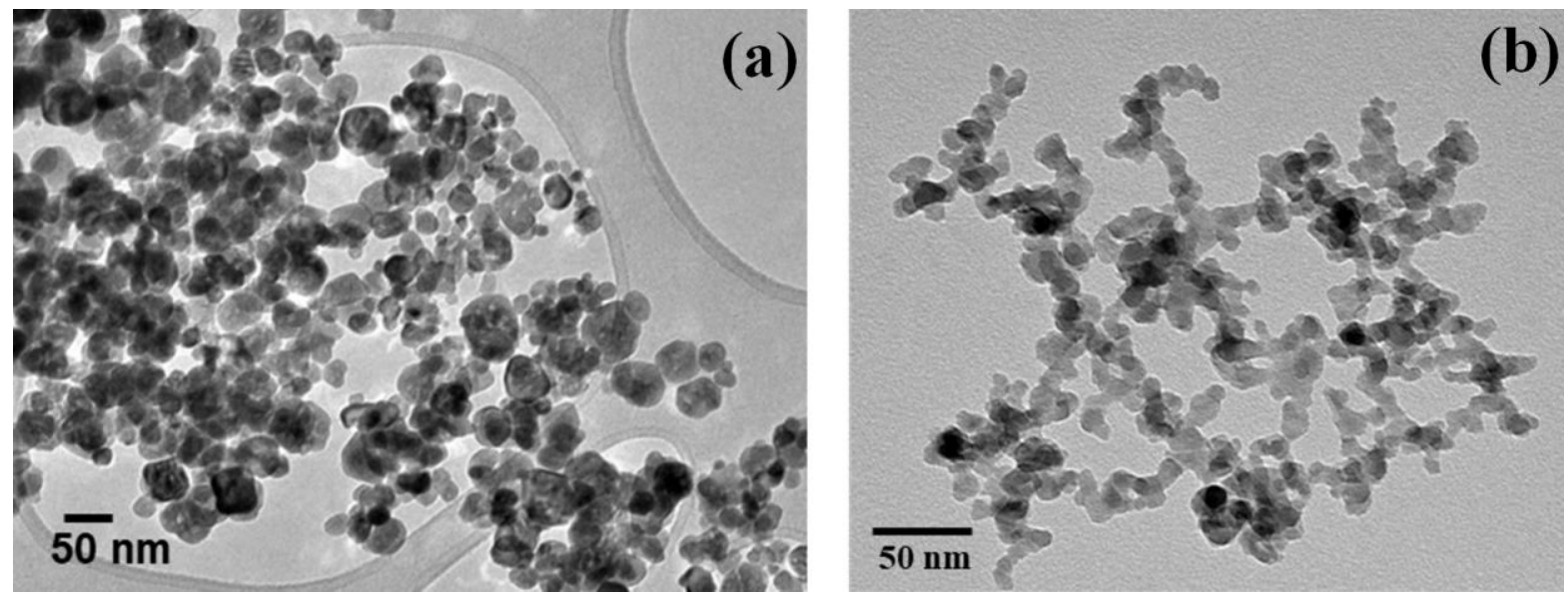

Figure S1: TEM images of (a) Hematite ${ }^{1}$ (b) Anatase $^{2}$ 
Table S1: The percentage of total Fe solubility

\begin{tabular}{|c|c|c|c|c|c|c|c|c|}
\hline \multirow[t]{4}{*}{ System } & \multicolumn{8}{|c|}{$\%$ total Fe solubility } \\
\hline & \multicolumn{4}{|c|}{ Dark condition } & \multicolumn{4}{|c|}{ Light condition } \\
\hline & \multicolumn{2}{|c|}{ deoxygenated } & \multicolumn{2}{|c|}{ oxygenated } & \multicolumn{2}{|c|}{ deoxygenated } & \multicolumn{2}{|c|}{ oxygenated } \\
\hline & $\begin{array}{c}\text { without } \\
\mathrm{TiO}_{2} \\
\end{array}$ & $\begin{array}{l}\text { with } \\
\mathrm{TiO}_{2} \\
\end{array}$ & $\begin{array}{c}\text { without } \\
\mathrm{TiO}_{2} \\
\end{array}$ & $\begin{array}{l}\text { with } \\
\mathrm{TiO}_{2} \\
\end{array}$ & $\begin{array}{c}\text { without } \\
\mathrm{TiO}_{2} \\
\end{array}$ & $\begin{array}{l}\text { with } \\
\mathrm{TiO}_{2}\end{array}$ & $\begin{array}{c}\text { without } \\
\mathrm{TiO}_{2} \\
\end{array}$ & with $\mathrm{TiO}_{2}$ \\
\hline $\mathrm{HCl}$ & $1.46 \pm 0.11$ & $0.37 \pm 0.9$ & $1.08 \pm 0.03$ & $0.78 \pm 0.07$ & $0.83 \pm 0.04$ & $1.20 \pm 0.05$ & $1.25 \pm 0.01$ & $1.79 \pm 0.01$ \\
\hline $\mathrm{H}_{2} \mathrm{SO}_{4}$ & $1.71 \pm 0.16$ & $0.69 \pm 0.11$ & $0.79 \pm 0.05$ & $0.75 \pm 0.07$ & $1.23 \pm 0.01$ & $2.74 \pm 0.11$ & $1.61 \pm 0.03$ & $2.63 \pm 0.20$ \\
\hline $\mathrm{HNO}_{3}$ & $0.68 \pm 0.02$ & $0.83 \pm 0.04$ & $2.65 \pm 0.08$ & $1.92 \pm 0.06$ & $0.85 \pm 0.01$ & $1.19 \pm 0.03$ & $1.14 \pm 0.04$ & $1.41 \pm 0.07$ \\
\hline $\begin{array}{l}\text { Controlled pH; } \\
\mathrm{HNO}_{3}\end{array}$ & $0.68 \pm 0.02$ & $0.69 \pm 0.01$ & -- & -- & -- & -- & -- & -- \\
\hline IPA:HNO3 & -- & -- & -- & -- & $0.98 \pm 0.02$ & $1.02 \pm 0.03$ & -- & -- \\
\hline
\end{tabular}

Fe Dissolution as a Function of Time in the Dark Deoxygenated/ $N_{2}$ Sparged Conditions

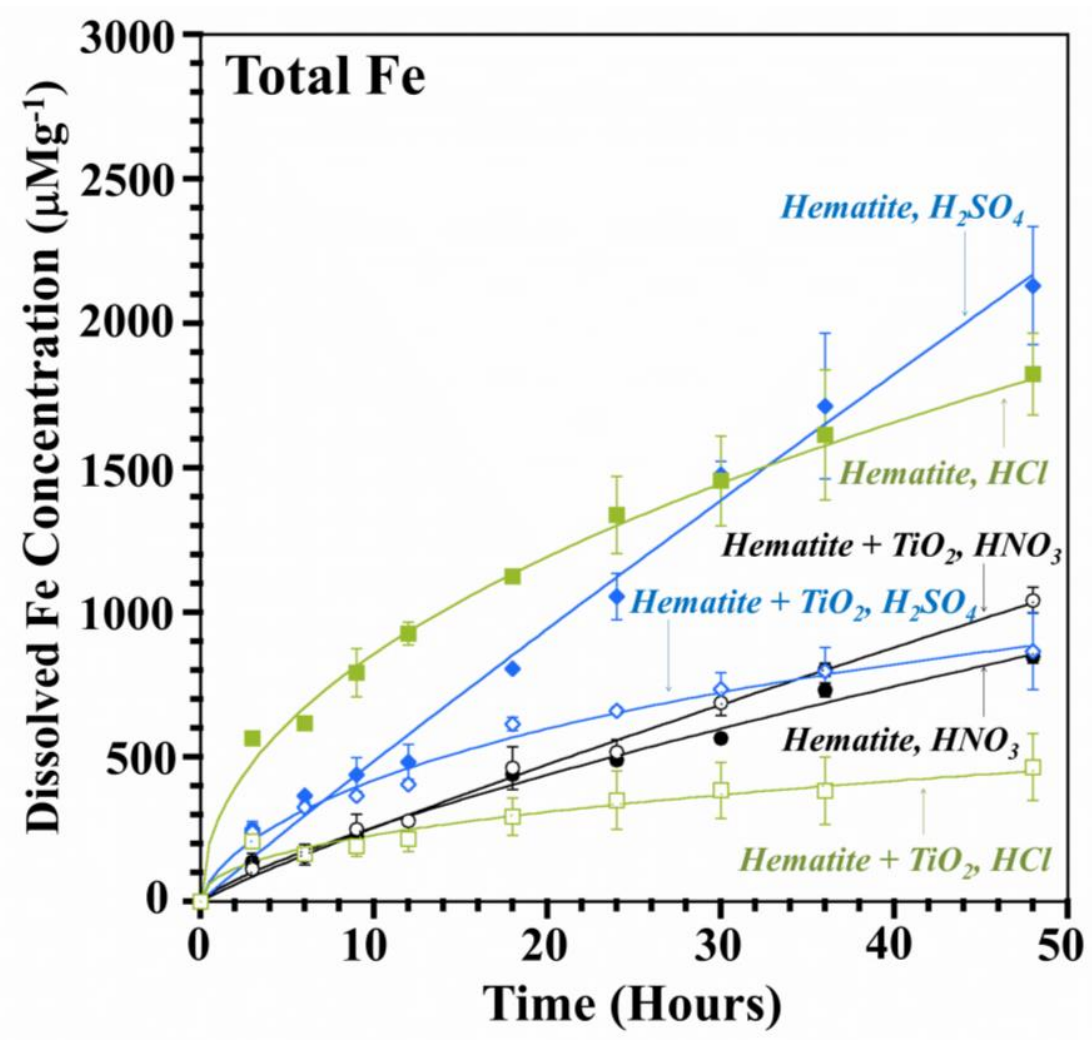

Figure S2: Total Fe dissolution from hematite and hematite with $\mathrm{TiO}_{2}$ as a function of time in nitrate, sulfate and chloride in deoxygenated dark conditions with initial $\mathrm{pH}$ of 2 . Open markers are hematite $+\mathrm{TiO}_{2}$ and closed markers are hematite alone. Circles, $\mathrm{HNO}_{3}$, squires, $\mathrm{HCl}$, and diamonds, $\mathrm{H}_{2} \mathrm{SO}_{4}$. The data has fitted to Langmuir type model. 
Fe Dissolution from hematite in the presence of amorphous titania - suggesting that the crystallinity of $\mathrm{TiO}_{2}$ does not affect the Fe dissolution enhancement

(a)

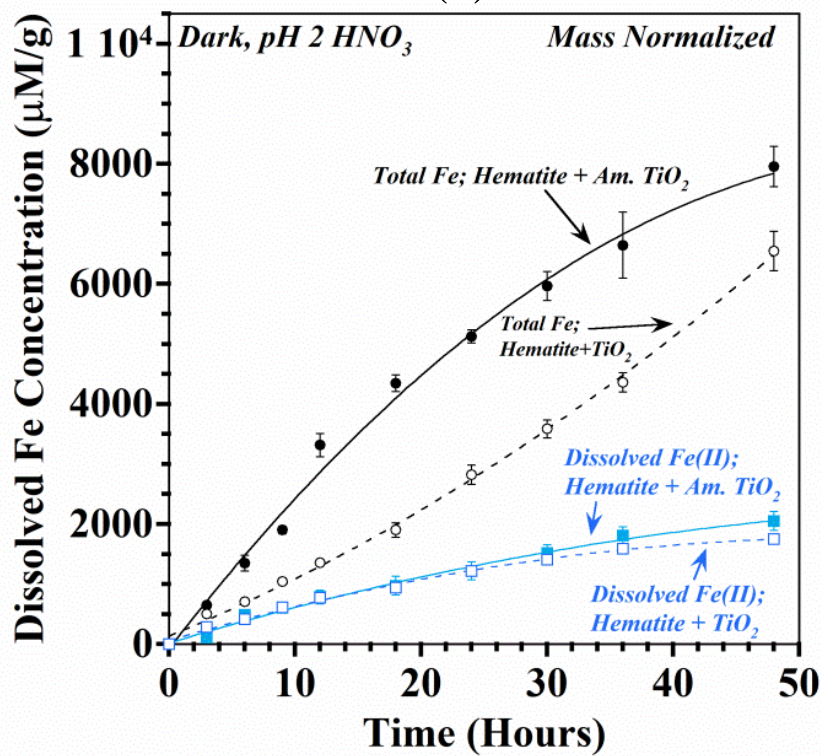

(b)

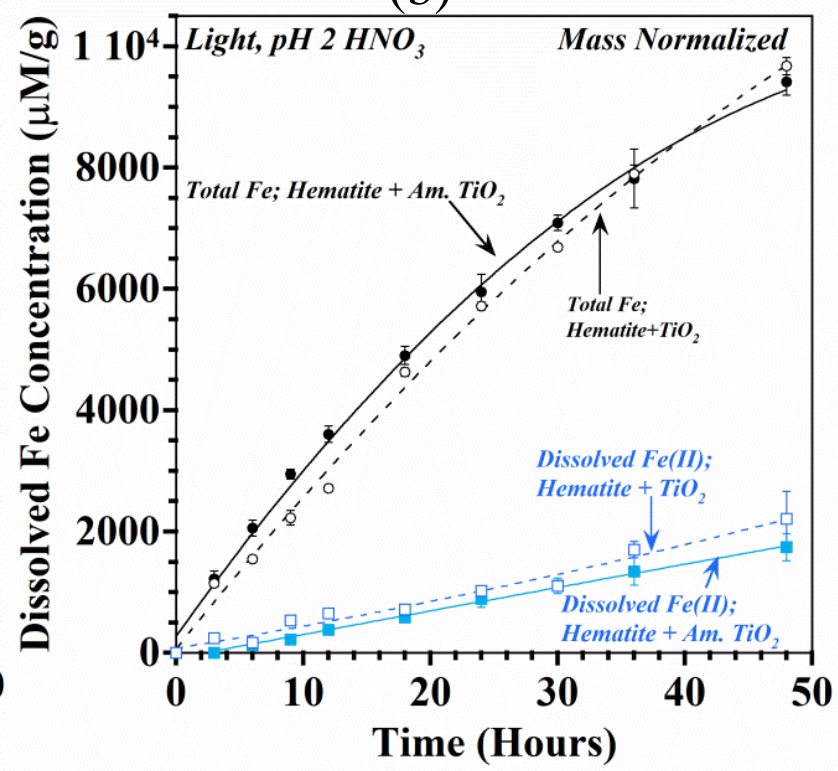

Figure S3: A comparison of the dissolved total $\mathrm{Fe}$ and $\mathrm{Fe}(\mathrm{II})$ concentrations from "hematite +amorphous titania mixture" and "hematite+ $\mathrm{TiO}_{2}$ mixture" in initial $\mathrm{pH}$ of $\mathrm{pH} 2 \mathrm{HNO}_{3}$, (a) dark (b) light. Data are fitted to Langmuir-type model. ${ }^{3}$

\section{Nitrite Assay Test ${ }^{4}$}

The nitrite was detected using mild condition brown ring test. First, A 25\% Fe(II) sulfate solution acidified with acetic acid was prepared. The nitrite solution was added slowly to this freshly prepared Fe(II) sulfate solution and the formation of a brown ring in the interface was observed. Controlled tests were conducted for sodium nitrite and for sodium nitrite plus sodium nitrate mixtures. Another negative control was conducted with sodium nitrate for which no brown ring formation was observed.

Reactions:

$\mathrm{NO}_{2}^{-}+\mathrm{CH}_{3} \mathrm{COOH} \rightarrow \mathrm{HNO}_{2}+\mathrm{CH}_{3} \mathrm{COO}^{-}$

$3 \mathrm{HNO}_{2} \rightarrow \mathrm{H}_{2} \mathrm{O}+\mathrm{HNO}_{3}+2 \mathrm{NO} \uparrow$

$\mathrm{Fe}^{2+}+\mathrm{SO}_{4}{ }^{2-}+\mathrm{NO} \uparrow \rightarrow\left[\mathrm{Fe}_{2} \mathrm{NO}\right] \mathrm{SO}_{4}$

$\left[\mathrm{Fe}_{2} \mathrm{NO}\right] \mathrm{SO}_{4}$ is responsible for the brown coloration. 


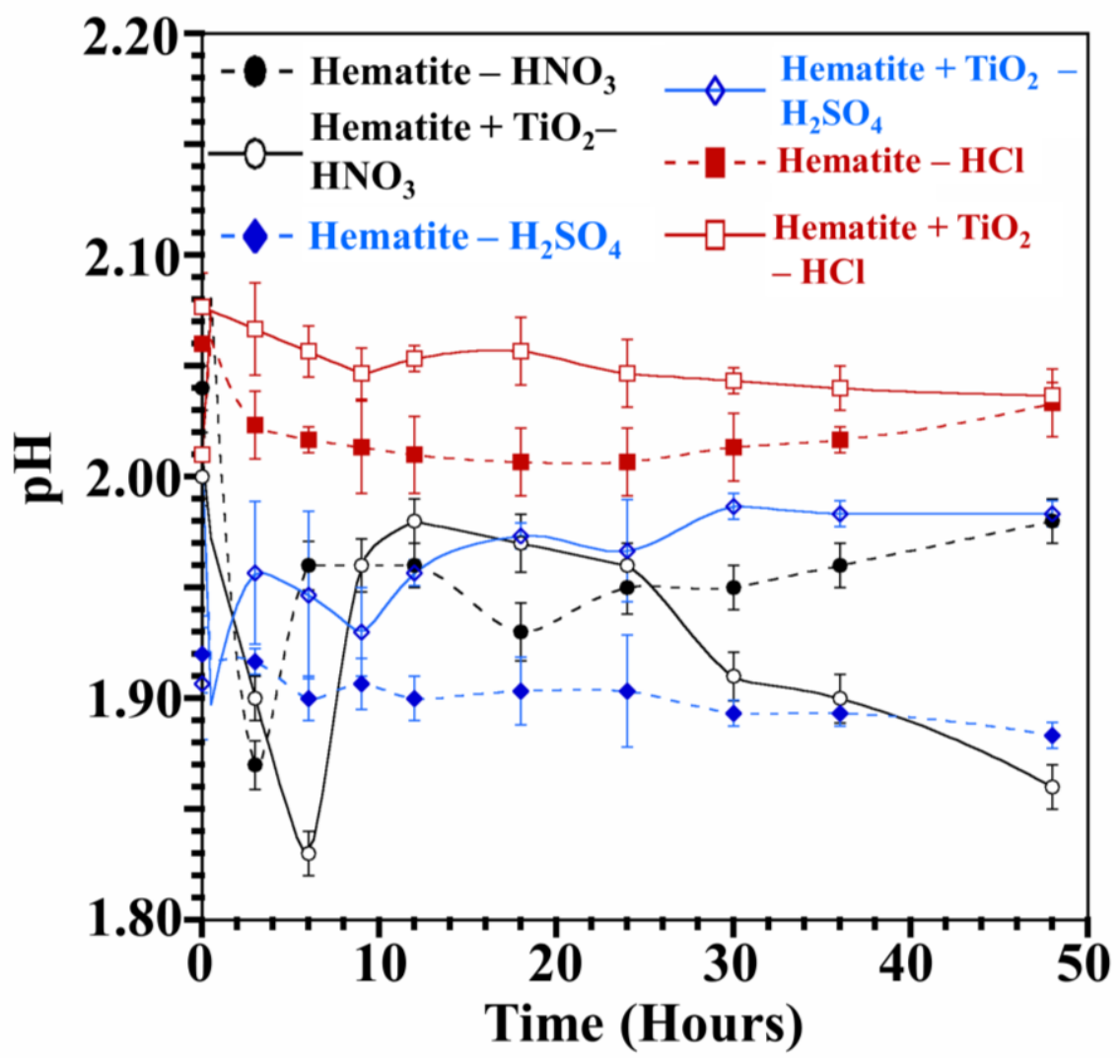

Figure S4: $\mathrm{pH}$ of the medium as a function of time for hematite and hematite with $\mathrm{TiO}_{2}$ systems in nitrate, sulfate and chloride systems in dark deoxygenated conditions.

Table S2: Post pH Assessment of the Experiments

\begin{tabular}{ccccccccc}
\hline System & \multicolumn{7}{c}{$\Delta \mathbf{p H}\left(\mathbf{p H}\right.$ of $\mathbf{4 8}^{\text {th }} \mathbf{h r}-$ initial $\left.\mathbf{p H}\right)$} \\
\hline \multicolumn{7}{c}{ Dark condition } \\
\hline \multicolumn{7}{c}{ deoxygenated } & \multicolumn{7}{c}{ oxygenated } & \multicolumn{3}{c}{ Light condition } \\
\hline & $\begin{array}{c}\text { Without } \\
\mathbf{T i O}_{2}\end{array}$ & $\begin{array}{c}\text { with } \\
\mathbf{T i O}_{2}\end{array}$ & $\begin{array}{c}\text { without } \\
\mathbf{T i O}_{2}\end{array}$ & $\begin{array}{c}\text { with } \\
\mathbf{T i O}_{2}\end{array}$ & $\begin{array}{c}\text { without } \\
\mathbf{T i O}_{2}\end{array}$ & $\begin{array}{c}\text { with } \\
\mathbf{T i O}_{2}\end{array}$ & $\begin{array}{c}\text { without } \\
\mathbf{T i O}_{2}\end{array}$ & withTiO \\
\hline $\mathbf{H C l}$ & 0.02 & 0.03 & 0.08 & 0.13 & 0.08 & 0.005 & 0.03 & 0.005 \\
\hline $\mathbf{H}_{2} \mathbf{S O}_{4}$ & -0.13 & -0.03 & -0.07 & -0.02 & -0.025 & -0.09 & -0.02 & -0.004 \\
\hline $\mathbf{H N O}_{3}$ & 0.03 & -0.15 & 0.04 & 0.02 & -0.01 & -0.05 & 0.04 & 0.09 \\
\hline & & & & & & & & \\
\hline
\end{tabular}




\section{pH variation in the sulfate medium}

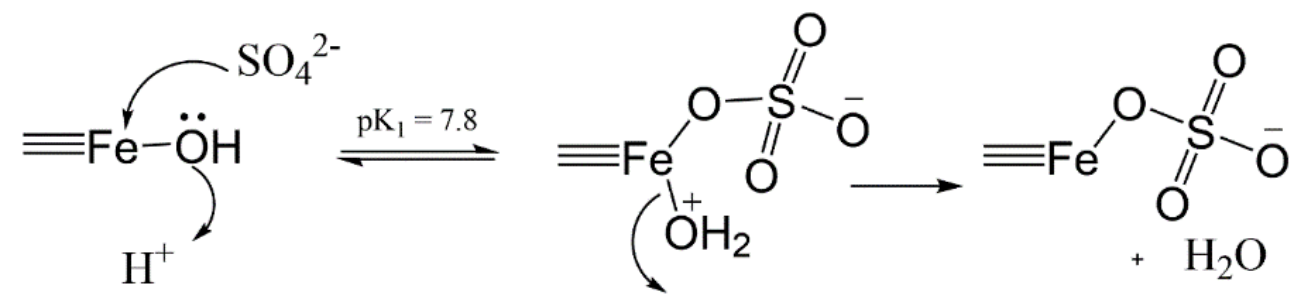

Elimination of water

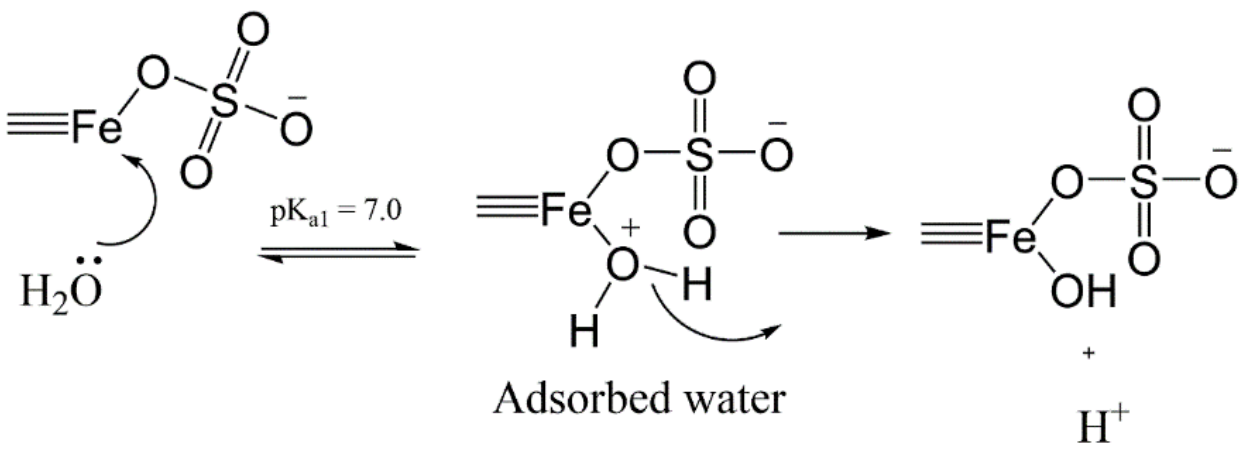

Elimination of a proton

Scheme 1: A possible mechanism for the adsorption of sulfate on hematite surface allowing an overall decrease of $\mathrm{pH}$ of the medium. $\mathrm{pK}_{1}$ and $\mathrm{pK}_{\mathrm{a} 1}$ were adopted from Blesa et al, 2000. ${ }^{5}$

As proton-promoted mechanisms consume protons, an increase of $\mathrm{pH}$ is expected as the reaction progresses. ${ }^{6-8}$ However, contrary to this, the $\mathrm{pH}$ was slightly decreased for $\mathrm{H}_{2} \mathrm{SO}_{4}$ (Table S2). Adsorption of oxyanions with multiple negative charges can either eliminate surface hydroxyl groups or exchange protons of proximal adsorbed water molecules, releasing protons to the medium. ${ }^{5,9-11}$ Thus, the observed lowering of $\mathrm{pH}$ for sulfate can be attributed to the possibility of establishing such an equilibrium as illustrated in Scheme 1. Here, the release of protons $\left(\mathrm{H}^{+}\right)$by dissociation of adsorbed water may also regenerate the surface hydroxyl groups. ${ }^{5,11}$ These low $\mathrm{pH}$ conditions can further enhance iron dissolution in the presence of sulfate as the proton-promoted dissolution becomes more favorable. 


\section{Iron Dissolution under Oxic Environment}

Dissolved oxygen can impact on mineral dissolution due to its capacity to change mobility and chemical speciation of dissolved metals. In order to study the impact of dissolved oxygen on hematite dissolution, experiments were conducted in media sparged with $\mathrm{O}_{2}$.

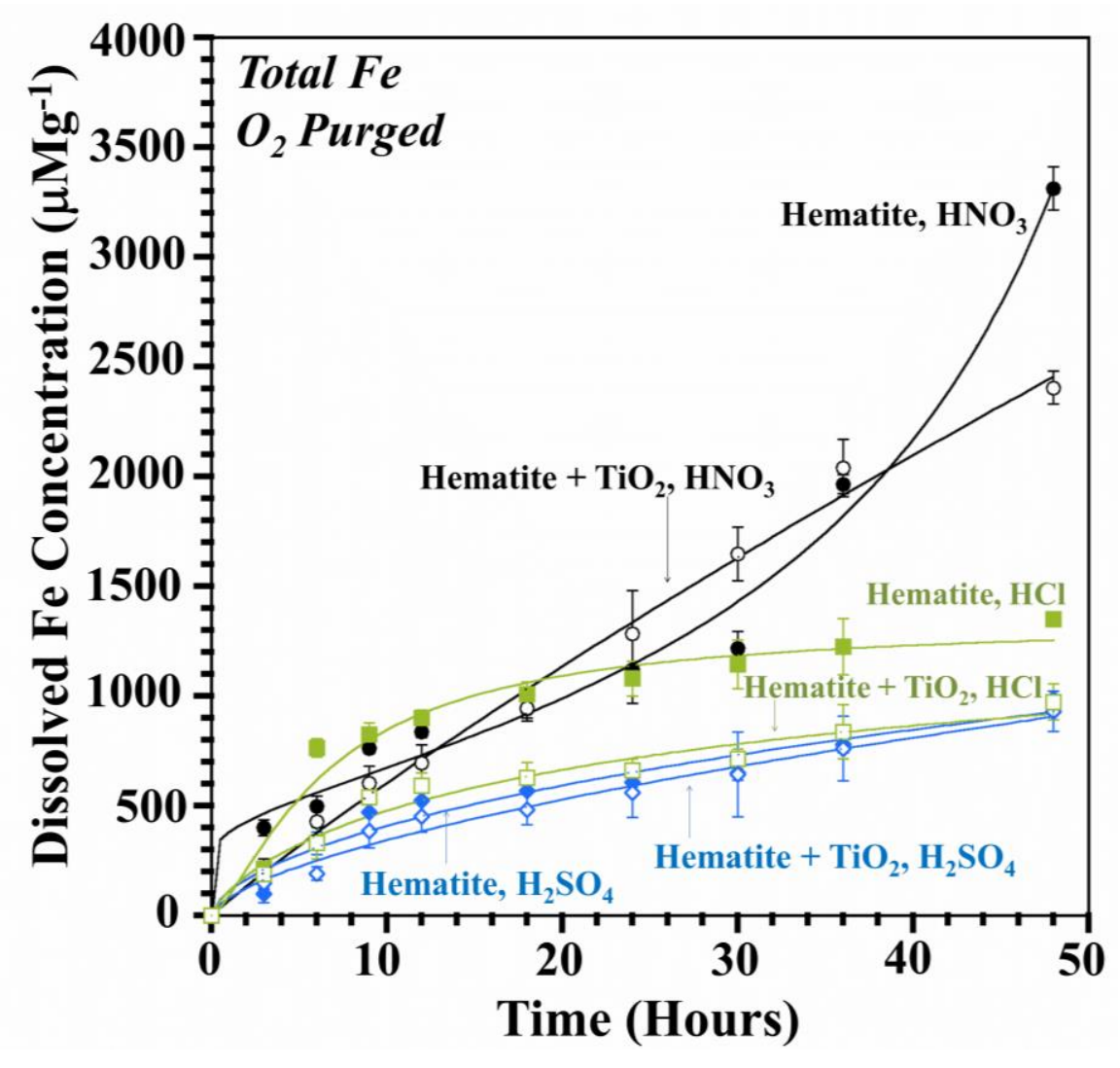

Figure S5: The total Fe dissolution as a function of time in the presence of dissolved oxygen under dark conditions. Open markers are hematite $+\mathrm{TiO}_{2}$ and closed markers are hematite alone. Circles, $\mathrm{HNO}_{3}$, squires, $\mathrm{HCl}$, and diamonds, $\mathrm{H}_{2} \mathrm{SO}_{4}$. The data has fitted to Langmuir type model.

\section{Role of Acid Anion in an Oxidizing Deliquescence Layer}

Figure $\mathrm{S5}$ shows total $\mathrm{Fe}$ dissolution from hematite with and without $\mathrm{TiO}_{2}$ in the presence of $\mathrm{HNO}_{3}, \mathrm{H}_{2} \mathrm{SO}_{4}$ and $\mathrm{HCl}$ in an oxidizing environment under dark conditions. The dissolution of hematite was highest in the presence of $\mathrm{HNO}_{3}$ followed by $\mathrm{HCl}$ and $\mathrm{H}_{2} \mathrm{SO}_{4}$ as opposed to deoxygenated conditions where the highest dissolution was observed in $\mathrm{H}_{2} \mathrm{SO}_{4}$ while the lowest was in the presence of $\mathrm{HNO}_{3}$. The initial rates of Fe dissolution were $52 \pm 3,32 \pm 1$ and $56 \pm 3 \mu \mathrm{M} \mathrm{g}^{-}$ ${ }^{1} \mathrm{hr}^{-1}$ for $\mathrm{HNO}_{3}, \mathrm{H}_{2} \mathrm{SO}_{4}$ and $\mathrm{HCl}$, respectively. When compared to their respective extent of $\mathrm{Fe}$ dissolutions under deoxygenated conditions, hematite dissolved at least 4-fold more under oxidizing conditions in the presence of $\mathrm{HNO}_{3}$ whereas the Fe dissolution was diminished 2.2-fold and 1.4-fold in the presence of $\mathrm{H}_{2} \mathrm{SO}_{4}$ and $\mathrm{HCl}$, respectively. 
Under oxic conditions, as the redox potential $\left(\mathrm{E}_{\mathrm{h}}\right)$ of the system is lower, the tendency for iron minerals to reprecipitate is higher. ${ }^{12} \mathrm{In}_{2} \mathrm{SO}_{4}$ solutions, hematite as well as ferric sulfate hydrates can precipitate thereby passivating the active sites on the surface. This can lead to lowering in extent of Fe dissolution compared to deoxygenated conditions. In the presence of $\mathrm{Cl}^{-}$anion, the low Fe dissolution could be due to the formation of minerals such as goethite, which demonstrated a limited dissolution capacity in $\mathrm{HCl}$ solutions. ${ }^{8,13}$ Similarly, the observed high solubility in $\mathrm{HNO}_{3}$ could be due to the high dissolution capacity of these precipitating minerals, i.e. high goethite dissolution in $\mathrm{HNO}_{3}$ solutions. The XRD pattern of acid-processed hematite under $\mathrm{HNO}_{3}$ and water vapor confirms the formation of $17 \%$ goethite (Figure S6). Formation of these minerals was not observed under deoxygenated conditions due to their lower tendency to precipitate in less aerated aqueous solutions. ${ }^{14}$ On the other hand, the reactivity of ferric oxide surfaces become more complex in the presence of oxygen. Hematite is well known to present oxygen vacancies where the number of vacancies depends on the environmental conditions such as humidity. ${ }^{11,15,16}$ Further, these vacancies can react with dissolved oxygen, as shown in equations $\mathbf{S 1}$ and $\mathbf{S 2}$, making the oxide surface more reactive to redox chemistry. ${ }^{11,15}$

$F e-($ oxygen vacancy $)+O_{2(g)}+e^{-} \leftrightarrow F e-O_{2(a d)}^{-} \quad$ eq.S1

$F e-O_{2(a d)}^{-}+e^{-} \leftrightarrow F e-2 O_{(a d)}^{-}$

eq.S2

Where $\mathrm{e}^{-}$is an electron trapped in the oxygen vacancy, $\sim 0.75 \mathrm{eV}$ below the conduction band of hematite. ${ }^{15}$ The generated $\mathrm{Fe}-2 \mathrm{O}^{-}$(ad) species is a potential electron acceptor. Nitrate can show strong redox activity both in aqueous and adsorbed phases. Therefore, it is possible that nitrate is involved in the surface chemistry on hematite surfaces in the presence of dissolved oxygen. However, further research is needed to understand the dissolution of hydrated hematite in the presence of dissolved oxygen by various environmentally relevant anions such as nitrate.

\section{$\underline{\text { Role of }}^{\mathrm{TiO}_{2}}{ }_{2}$ in Oxic Environments during Nighttime}

The extent of total Fe dissolution in hematite mixed with $\mathrm{TiO}_{2}$ under oxic conditions was lower than that of only hematite (Figure S6). Hematite mixed with $\mathrm{TiO}_{2}$ dissolved at least 1.4-fold less in the presence of $\mathrm{HNO}_{3}$ and $\mathrm{HCl}$, and slightly lower ( $\sim 1$-1-fold) in $\mathrm{H}_{2} \mathrm{SO}_{4}$ than their respective systems containing only hematite. The competition among different mineral surfaces for acid anions, similar to that in deoxygenated conditions, could cause the observed low Fe dissolution. However, a redox cycling between minerals and the adsorbed nitrate may not be prominent under oxic environments, unlike the anoxic conditions; hence all three anions tested demonstrated a decrease of the dissolved total Fe concentration.

In a deliquescence layer rich with dissolved oxygen, the Fe(II) formation was not observed for any of the six systems. For the $\mathrm{HNO}_{3}$ system, nitrite formation was tested and found not to occur. The post $\mathrm{pH}$ assessment suggests the slight decrease only for $\mathrm{H}_{2} \mathrm{SO}_{4}$ systems. (Table S2) 


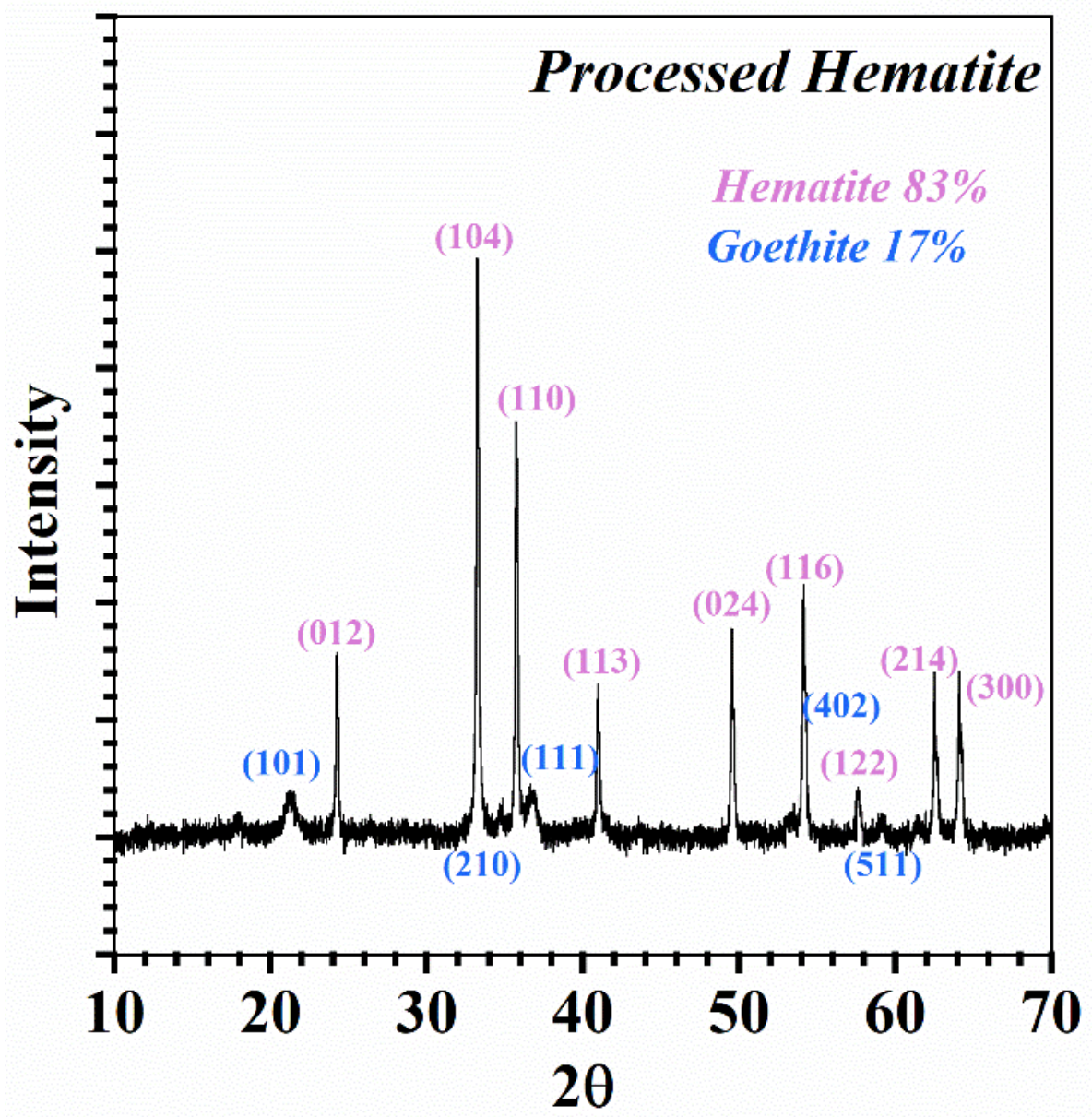

Figure S6: XRD image of pure hematite exposed to gaseous $\mathrm{HNO}_{3}$ for 48 hours in the humid conditions 


\section{Dissolved Fe Concentration as a function of Time in the Simulated Sunlight}

(a)

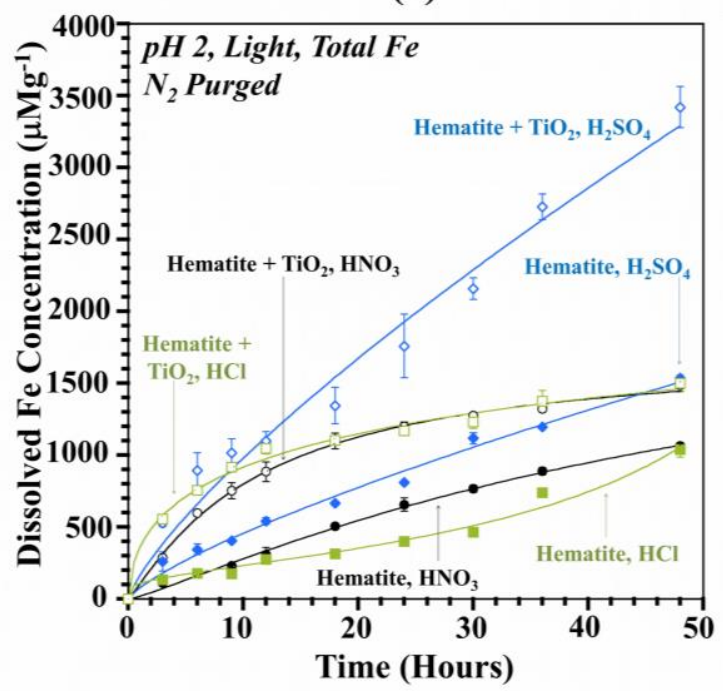

(c)

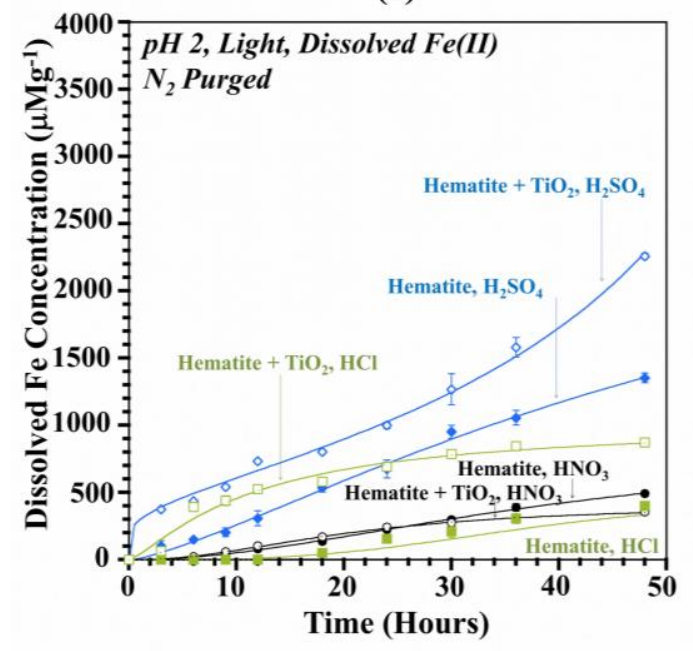

(b)

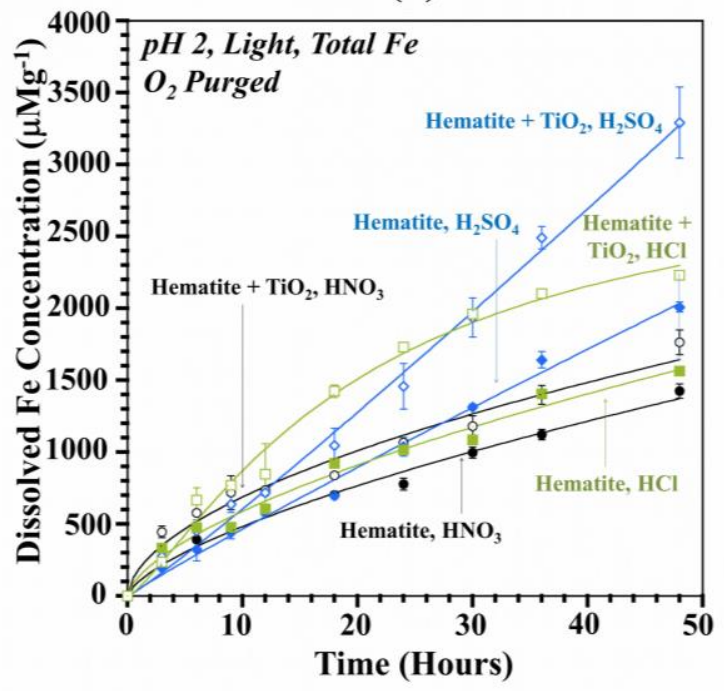

(d)

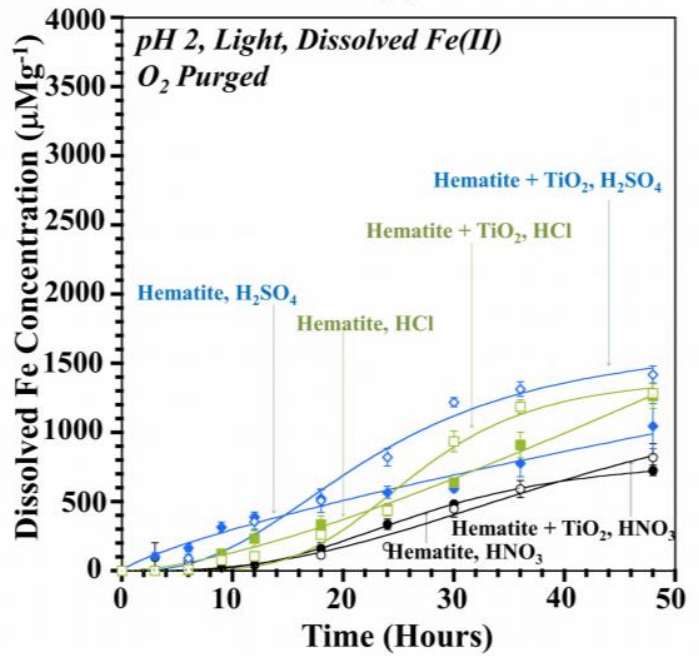

Figure S7: The total Fe dissolution from hematite as a function of time in the presence of simulated sunlight. The total dissolved Fe in (a) anoxic conditions (b) oxic conditions, and dissolved Fe(II) in (c) anoxic conditions (d) oxic conditions. Open markers are hematite $+\mathrm{TiO}_{2}$ and closed markers are hematite alone. Circles, $\mathrm{HNO}_{3}$, squires, $\mathrm{HCl}$, and diamonds, $\mathrm{H}_{2} \mathrm{SO}_{4}$. The data has fitted to Langmuir type model. 
(a)

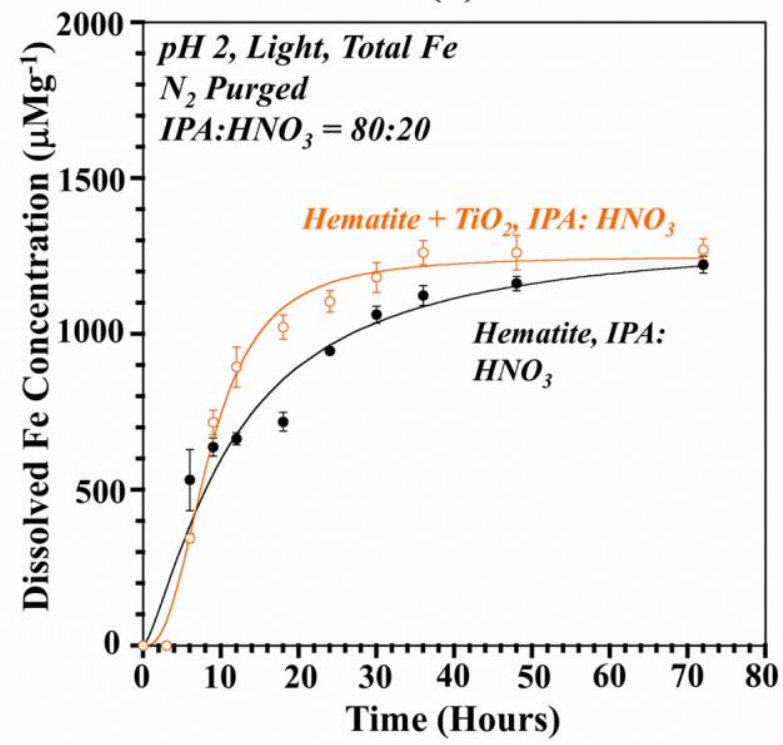

(b)

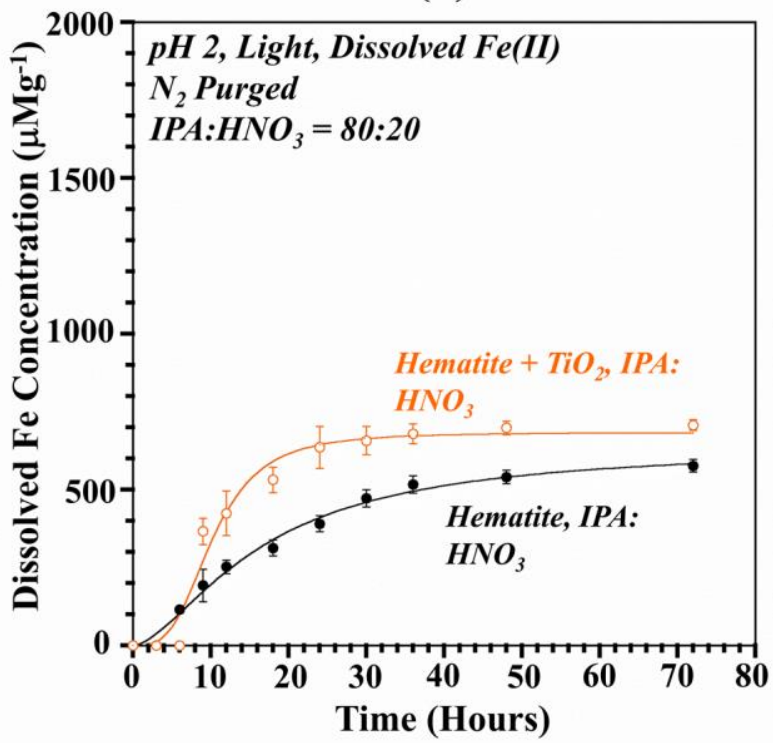

Figure S8: The dissolved Fe from hematite alone and hematite with $\mathrm{TiO}_{2}$ in $\mathrm{IPA}: \mathrm{HNO}_{3}$ medium as a function of time. (a) total dissolved Fe, (b) Dissolved Fe(II). Open circles are for hematite with $\mathrm{TiO}_{2}$ and closed circles are hematite alone. Data are fitted to Langmuir type model.

(1) Hettiarachchi, E.; Hurab, O.; Rubasinghege, G. Atmospheric Processing and Iron Mobilization of Ilmenite: Iron-Containing Ternary Oxide in Mineral Dust Aerosol. J. Phys. Chem. A 2018, 122, 1291-1302. https://doi.org/10.1021/acs.jpca.7b11320.

(2) Hettiarachchi, E.; Reynolds, R. L.; Goldstein, H. L.; Moskowitz, B.; Rubasinghege, G. Iron Dissolution and Speciation in Atmospheric Mineral Dust: Metal-Metal Synergistic and Antagonistic Effects. Atmos. Environ. 2018, 187, 417-423. https://doi.org/10.1016/j.atmosenv.2018.06.010.

(3) Hettiarachchi, E.; Reynolds, R. L.; Goldstein, H. L.; Moskowitz, B.; Rubasinghege, G. Bioavailable Iron Production in Airborne Mineral Dust: Controls by Chemical Composition and Solar Flux. Atmos. Environ. 2019, 205, 90-102. https://doi.org/10.1016/j.atmosenv.2019.02.037.

(4) Svehla, G. Vogel's Textbook Of Macro And SemiMicro Qualitative Inorganic Analysis, 5th ed.; Longman Group Limited: London and New York, 1979.

(5) Blesa, M. A.; Weisz, A. D.; Morando, P. J.; Salfity, J. A.; Magaz, G. E.; Regazzoni, A. E. The Interaction of Metal Oxide Surfaces with Complexing Agents Dissolved in Water. Coord. Chem. Rev. 2000, 196 (1), 31-63. https://doi.org/10.1016/S0010-8545(99)00005-3.

(6) Parfitt, G. D. Surface Chemistry of Oxides. Pure Appl. Chem. 1976, 48 (4), 415-418.

(7) Wiederhold, J. G.; Kraemer, S. M.; Teutsch, N.; Borer, P. M.; Halliday, A. N.; Kretzschmar, R. Iron Isotope Fractionation during Proton-Promoted, Ligand-Controlled, and Reductive Dissolution of Goethite. Environ. Sci. Technol. 2006, 40, 3787-3793. 
https://doi.org/10.1021/es052228y.

(8) Rubasinghege, G.; Lentz, R. W.; Scherer, M. M.; Grassian, V. H. Simulated Atmospheric Processing of Iron Oxyhydroxide Minerals at Low PH: Roles of Particle Size and Acid Anion in Iron Dissolution. Proc. Natl. Acad. Sci. 2010, 107, 6628-6633. https://doi.org/10.1073/pnas.0910809107.

(9) Al-Abadleh, H. A.; Al-Hosney, H. A.; Grassian, V. H. Oxide and Carbonate Surfaces as Environmental Interfaces: The Importance of Water in Surface Composition and Surface Reactivity. J. Mol. Catal. A Chem. 2005, 228 (1-2), 47-54. https://doi.org/10.1016/j.molcata.2004.09.059.

(10) Bordiga, S.; Groppo, E.; Agostini, G.; van Bokhoven, J. A.; Lamberti, C. Reactivity of Surface Species in Heterogeneous Catalysts Probed by In Situ X-Ray Absorption Techniques. Chem. Rev. 2013, 113 (3), 1736-1850. https://doi.org/10.1021/cr2000898.

(11) Grassian, V. H. Surface Science of Complex Environmental Interfaces: Oxide and Carbonate Surfaces in Dynamic Equilibrium with Water Vapor. Surf. Sci. 2008, 602, 29552962. https://doi.org/10.1016/j.susc.2008.07.039.

(12) Brezonik, P.; Arnold, W. Water Chemistry An Introduction to the Chemistry of Natural and Engineered Aquatic Systems, 1st ed.; Oxford University Press: New York, 2011. https://doi.org/978-0-19-973072-8.

(13) Riveros, P. A.; Dutrizac, J. E. The Precipitation of Hematite from Ferric Chloride Media. Hydrometallurgy 1997, 46 (1-2), 85-104. https://doi.org/10.1016/S0304-386X(97)000030 .

(14) Wehrli, B. Redox Reactions of Metal Ions at Mineral Surfaces. In Aquatic Chemical Kinetics-Reaction Rates of Processes in Natural Waters; Stumm, W., Ed.; WileyInterscience: New York, 1990; pp 311-335.

(15) Lilley, C. M. The Role of Technology in Managing People Who Have Been Convicted of Internet Child Abuse Image Offences. Child Abus. Rev. 2016, 25 (5), 386-398. https://doi.org/10.1002/car.2444.

(16) Toledano, D. S.; Henrich, V. E. Kinetics of $\mathrm{SO}_{2}$ adsorption on Photoexcited $\alpha-\mathrm{Fe}_{2} \mathrm{O}_{3}$. J. Phys. Chem. B 2001, 105, 3872-3877. https://doi.org/10.1021/jp003327v. 